\title{
Postmodernist Perspective of Development and its applications on Contemporary Trends of Development in Africa: a review of the conjectures
}

\author{
${ }^{1}$ Adole Raphael Audu, ${ }^{2}$ Ayuba Kule Babale, ${ }^{3}$ Emmanuel Gwambeka \\ ${ }^{I}$ Department of Public Administration Faculty of Management Sciences University of Maiduguri Nigeria \\ ${ }^{2}$ Department of Social and Community Development College of Administrative and Business Studies (CABS) \\ Potiskum, Yobe State Nigeria \\ ${ }^{3}$ Department of Sociology Faculty of Social Sciences Gombe State University Gombe State Nigeria
}

\begin{abstract}
This paper seeks to examine the postmodernist perspective of development and its applications on the contemporary trends of development in Africa. The paper reveals that postmodernism is an aggressively expansive stage in global capitalism; the weakening of the centralized state power in developed and developing societies; the patterning of life by an increasingly powerful and penetrative technology that controls production and promotes consumerism and the development of liberationist social movement based not in class but in other forms of identity and nationalism such as race, gender, sexual orientation, the environment and the like. Secondary data was used for the paper. The paper contends that the postmodern society or late capitalism as it is also known has negatively affected the development of Africa as her cultural identity, attitude, behaviour and nationalism are gradually being replaced by a more dominant western culture as a result of globalization. The paper recommends among others that African leaders should endeavour to control the access and the use of the internet to protect the influence of western culture on the African continent.
\end{abstract}

Keywords: postmodernism, modernism, globalization, development, Africa.

\section{Introduction}

Following the demise of the Union of Soviet Socialist Republic (USSR) and the eventual erosion of international socialism as strong and contending ideological platform in the global political, social and economic arena especially in the early 1990s marked the tragic end of the mortal antagonism between the two rigidly hostile blocs and the immediate domination of World politics by the western powers led by United States of America, Britain, France, Canada, Japan, Germany and Italy. Through the activities of Multinational Corporations they organize increasingly an integrated economy and financial activity across national borders and produced sourced markets and raw materials for worldwide competitive advantage. The use of Information Technology (IT) as an instrument of globalization has its implication on the development of Africa. Globalization has in fact encouraged ferocious socio-economic and political competition that Africa is presently struggling with. Since the fall of the USSR the global economy has continued to experience some fundamental changes in nearly all ramifications including even language of global discourse. This trend is currently being pursued with vigor by the now acclaimed instruments of globalization that is the Reform of Breton Woods Institutions (IMF and the World Bank), World Trade Organization (WTO), and the group of the most industrialized nations in the world the (G8).

According to Banjo (2000[1]), these are the wicked machines of the imperialists which have their pedigrees in the ideological framework of the west and its monopolistic view of what the world should look like. That is why Banjo (2000[2]) still contends that: "The rules and regulations of these agents of imperialism are fundamentally unfair to the workings of the poor people around the world". Critics believed that the economic, political and cultural integration of the world into a global village is to further subjugate the economies of the Less Developed Countries (LDCs) to the absolute control of the USA and her western allies. The position of the Less Developed Countries under this dispensation particularly Africa is precarious. So far, some levels of assessment are continually being conducted by individuals, Corporate Organizations and governmental agencies to measure the performance of globalization using index. Principal among which is the A.T. Kearney/Foreign Policy Globalization Index. Khor (2001[3]) asserts that:"The reasons for the changing perception of the altitude towards globalization are many". Among the important factors are the lack of tangible benefits to most African countries from opening their economies, despite the well published claim of export and income gains; the economic losses and social dislocation that are caused to many developing countries by rapid financial and trade liberalization, the growing inequalities of wealth and opportunities arising from globalization and the perception that environmental, social and cultural problems have been made worse by the working of global free-market 
economy as seen in most African Countries. Globalization has in fact ushered Africa in to the era of postmodernism through the use of information technology and trade liberalization.

It is against this backdrop that the researchers assess the post-modernist perspective of development and its applications on contemporary trends of development in Africa.

\section{Conceptual clarifications}

The post modernist perspective of development and its applications to contemporary trends of development in Africa cannot be completely comprehended if we fail to clarify some of the concepts used in this paper.

Modernity: Most classical sociologists have attempted to explain the theory of modernity for instance Marx (1987[3]) viewed modernity as the advances brought about by the transition from traditional societies to capitalism. He restricted himself largely to a critique of that economic system (Capitalism) and its deformities like: alienation, exploitation, domination and the like. To Weber (1986[4]) the most defining problem of the modern world was the expansion of formal rationality at the expense of the other types of rationality and the resulting emergence of the iron cage of rationality. Weber emphasizes the advantages of bureaucracy over earlier organizational forms.

The above definitions of modernity advanced by the above classical theorists were clearly summarized by Giddens (1990[5]) as follows:

1. The presence of capitalism which is characterized by commodity production, private ownership of capital, property, less wage and a class system derived from these characteristics.

2. Industrialism; which involves the use of inanimate power sources and machinery to produce goods. Industrialism also affects an array of other settings such as transportation, communication and domestic life.

3. Surveillance capacities; refers to the supervision of the activities of subject populations in the political sphere.

4. The final institutional dimension of modernity is military power or the control of the means of violence, including the industrialization of war.

It is also in this light that Row stow (2006[6]) also describes the characteristics of a modernized society: as a highly differentiated and functionally specific system of governmental organization. A society with a high degree of integration within the governmental structure. In a modernized society, there is the prevalence of rational and secular procedures for making political decisions. More so, there is a wide spread and effective sense of popular identification with the history, territory and national identity of the State and finally, the allocation of political roles by achievements rather than by ascriptions.

The advanced capitalist societies are very good example of societies with the characteristics described above. They are most at times referred to as classic societies because of the high level of their political, economic and social organization. Africa, on the other hand is described as a modernizing (Transitional) society. Johari citing Huntington (2006[7]) highlighted the following as the basic features of a modernizing society.

1. It is a revolutionary process; change from tradition to modernity consequently involves a radical change in the patterns of human life.

2. It is a complex process. It cannot be easily reduced to a single factor or to a single dimension.

3. It is a systematic process: Changes in one factor is related to and affect changes in other factors.

4. It is an irreversible process. There may be temporary breakdown and occasional reversals in the elements of modernizing process, as a whole it is essentially a secular trend.

5. It is a phased process. It is possible to distinguish between levels or phases of modernization through which all societies will move.

As earlier stated, Africa has the above striking features, in that politics and government are shaped by the basic facts of scarce economic resources, extensive poverty and inequality and a relatively weak position in the international system. Again, the political legitimacy of most of African States is very weak. Most of the citizens have no faith in their political leaders or perhaps in the very nature of the political system of their country. In fact the effective power of governance in African societies is very limited. The State may have little or no ability to exert its authority much beyond the capital city and a few large urban centres.

Having examined the features of modern and modernizing societies, it is pertinent to also discuss the features of a postmodern society so as to critically examine the postmodernist perspectives of development and its application to contemporary trends of development in Africa which is in fact the main concern of this paper.

Postmodernism: According to Kuhn (1996[8]) post modernism is a rapid change of the basis of scientific knowledge to a provisional consensus among scientists. That it is a "paradigm shift" in the structure of scientific revolutions. Lyotard (1964[9]) "identified the postmodern condition as a crisis in the discourse of the human sciences latent in modernism but catapulted to the fore by the advent of the computerized or telemetric era". For Baudrillard (1980[10]) the introduction of simulacra and simulation in the postmodern era introduced the 
concept that reality or the principle of the "real" is short-circuited by the interchangeability of signs in an era whose communicative and semantic acts are dominated by electronic media and digital technologies.

Baudrillard proposes the notion that in such a state, where subjects are detached from the outcomes of events (political, literary, artistic, personal or otherwise), events no longer hold any particular sway on the subject nor have any identifiable context; they therefore have the effect of producing widespread indifference, detachment and passivity in industrialized populations as a period of the cultural logic of late capitalism while Rorty (1991[11]) believes that post modernism has a special commitment to social liberalism.

Deriving from the above assumptions, it is pertinent to state here that postmodernism suggests a break or extinction of modern movement. It portrays the end of modern ideology in art, social class to an era of globalization. As stated earlier, postmodernism is an abstract expressionism in painting, music, science, architecture, poetry, films, politics etc. It is from the realm of architectural debates that the conception of postmodernism was generated. A Postmodern society is meant to bear a strong family resemblance to all those more ambitious sociological generalizations which bring an inauguration of a whole new type of society. Daniel (1999[12]) clearly described a postmodern society as a Postindustrial and consumer society, a media society, an information society, an electronic society, a high tech society and the like.

The post modern society in all ramifications and with the new social formation has no respect for the laws of capitalism, namely the primacy of industrial production and the omnipresence of class struggle. A postmodern society ushers in a more pure stage of capitalism (Globalization).

\section{Theoretical Framework}

So many writers have come up with assumptions in other to explain the relationship among States globally. For Instance, Parson (1964) Structural-Functionalism, Wallenstein (1981) World System Theory, and Ake (1986) Dependency theory but for the purpose of this paper, theory of globalization will be the theoretical framework. Within the parameters of the foregoing, Macewan (1990[13]) stated that globalization could be correctly be defined from the institutional perspective as the spread of capitalism. Globalization could also be seen as a phenomenon that has seriously gained momentum in the late 20th century. Globalization has brought about a corresponding increase in trade and capital flow as well as labour mobility amongst and between countries. According to Todaro (2000[14]) globalization is the increasing integration of national economy into expanding international market. In similar manner, Samuelson and Nordhaus (2001[15]) denote the concept as an increase in economic integration among nations, as seen today in the dramatic growth in the flow of goods, services and capital across national borders while the International Monetary Fund (2005[16]) in its attempt to look at the meaning of globalization described it as acceleration in the pace of growth of international trade in goods, services and financial assets relative to the rate of growth in domestic trade. Multinational Corporations within the context of our analysis can also be referred to as Transnational Corporations. They are Corporations that are registered and operates in more than one country at a time. Generally, the corporation has its Headquarters in one country and operates wholly or partially as subsidiaries in other countries (Encyclopedia Britannica [17]). According to Microsoft Encarta (2009 [18]) Multinational Corporations also engages in Foreign Direct Investment (FDI) that is, one country by citizens of another country in other cases, Multinational Corporation undertake what is known as Greenfield Investment by creating new facilities or activities across countries.

\section{Postmodernism and contemporary trends of development in Africa}

The preceding section of this paper has clearly given us a panoramic view of a postmodern society. A postmodernist perspective of development is such that development is seen as the projector of a global contamination of the people, culture and environment. A society which Beck (1992[19]) described as a risk society. A situation where politics is no longer left to the central government but increasingly becomes the province of various subgroups as well as of individuals. It is in the light of this fact that Castells (1998[20) advanced that the postmodernist perspective on development is all about informational capitalism that creates informational societies "a mode of development in which the main source of production is the qualitative capacity to optimize the combination and use of factors of production on the basis of knowledge and information. The spread of information especially information capitalism leads to the emergence of oppositional social movements based on self and identity. A process which a social actor recognizes itself and constructs meaning primarily on the basis of a given cultural attribute or set of attributes, to the exclusion of a broader reference to other social structures.

The application of the postmodernist perspective of development as it relates to contemporary trends of African development can be examined from the socio-cultural, political and economic dimensions as discussed hereunder. 


\section{Socio-cultural dimension of postmodernist perspective of development in Africa.}

Africa in this period of information dominance is already losing its cultural dominance and identity to western cultural influence. Postmodernism is gradually dispelling the art, language, custom and the mode of dressing in African societies. There is a fresh wave of ever more novel seeming goods from clothing to music. The postmodern society is stressing its own offensive features from obscurity and sexually explicit material to psychological squalor and overt expressions of social and political defiance, which transcend anything that might have been imagined at the most extreme moments of high modernism.

It is worthy to mention here that Africa is still grappling with the negative effect of globalization. The effect of globalization on Africa today cannot be quantified as it has affected almost all aspect of life in the African society. The importation of western culture through social Networks like the YouTube, Twitter, Face book, Skype and the general use of the internet has raped and will continue to rape Africa culturally, socially, and mentally.

African youths today find it difficult to dress decently particularly in our higher Institutions of learning. The kind of music and films they also watch are negatively influencing their mode, attitude, behavior and identity. The proliferation of this negative culture through globalization is adversely affecting Africa's development. Post- modernism has indeed introduced globalization which is a powerful force for the improvement in the material well being of human kind that would aid developing countries to create "better economic environment" so as to leap frog into the information age, improve the access to technology, speed development and enhance global harmony but its holocaust effects on the political, social, economic and cultural nerves of developing countries such as Africa cannot be over emphasized. Post-modernism has gone from a stage in monopoly capitalism in which culture was at least to some degree autonomous to an explosion of culture in multinational capitalism as Jameson (1984[21]) clearly puts it:

A prodigious expansion of culture throughout the social realm, to the point at which everything in our life- from economic value and state power to practices and to the very structure of the psyche itself can be said to have become "cultural" in some original and as yet untheorized sense. This perhaps startling propositions is however, substantively quite consistent with the previous diagnosis of a society of the image or the simulacrum and a transformation of the "real" into so many pseudo events.

Postmodernism is a new form of "cultural domination" in the world. A force field in which different kinds of cultural impulses must make their way. Thus, post modernism is a new systematic cultural norm which is made up of a range of quite heterogeneous elements that would end up eroding the rich African cultural heritage.

\section{Economic dimension of postmodernist perspective of development and its implications on} Africa's development

Postmodernism (or multi-nationalism) is calling for greater expansion of capitalism around the globe. Postmodernist economic perspective of development imply more fundamental change or break; changes determined by hyper stylistic innovation. This is a period which Jameson (1984[22]) described as late capitalism. According to him; "this whole global yet American post modern culture is the internal and super structural expression of a whole new wave of American military and economic domination throughout the world. In this sense, as throughout class history the underside of culture is blood, torture, death and horror".

The African economy is still today described as a mono-cultural or monolithic economy; an economy which is basically agrarian and practically unproductive. The economy of Africa is no doubt one of the major players in the international economic arena due to its size and the huge availability of both human and natural resources in the continent. The presence of Africa on the political and economic map of the world has indeed created an avenue for ready market where goods and services could be easily transferred to the capitalist west for their development. That is why Helbroner (1985 [23]) posited that the logic of market is to locate economic activities where they are most productive and profitable. The logic of such relation is for state to capture and control the process of economic growth and capital accumulation. In the postmodern society Africa would find it difficult to carry out such relation whether economic or political as a result of it's over dependence on the capitalist west. The inevitable posers are: can Africa compete globally with its poor industrial base? Can Africa make 3D films? Or can it construct monumental stadium like the Bird's Nest Stadium in China? It is in fact practically impossible for Africa to compete globally because of it's over reliance on the capitalist west for foreign investments. Globalization has made it easy for International financial institutions and multi-national companies to be strong players in the African economy. They dictate African economic policies as African leaders today look up to the United States of America, Britain, China and the like for their economic development. It is in the light of the foregoing that Kellner (1989[[24]) clearly opined that the postmodern moment had arrived and perplexed intellectuals, artists, and cultural entrepreneurs. Since it is a new historical epoch with new cultural identity and economy, they have continue to wonder whether they should get on the 
bandwagon and join the carnival, or sit on the sidelines until the new fad disappeared into the whirl of cultural fashion.

\section{Political dimension of postmodernist perspective of development and the place of Africa's development}

The post-modernists call for a global cognitive mapping on a social and political scale a situation in which individuals and social groups cognitively map their individual and social relationship to local, national and international class realities. It must be mentioned here that in a postmodern political arrangement traditional production has disappeared as such social classes of the classical type no longer exist. Jameson (2010[25]) said it is an aesthetic of cognitive mapping that would usher a pedagogical political culture which seeks to endow the individual subject with some new heightened sense of place in the global system. The political form of postmodernism is a projection of an enormously complex representational dialectic and a more transparent national space.

Deriving from the above analysis the African political leaders are finding it difficult to cope with this new political art due to the fragile nature of Africa political systems. Political Systems in Africa is virtually unstable; frequent civil wars; coups de' tat, and political violence. The position of individuals living in Africa is deplorable. The poverty level is so high particularly in African States such as Rwanda, Democratic Republic of Congo, Nigeria, Zimbabwe Ethiopia, Somali, Sudan etc. There is an absolute failure of leadership and the systematic failure of leadership in Africa. The post-modern political world would in fact incapacitate the policy independence of African states because of the dominant culture of globalization and over dependence on the western world for political and economic solutions.

Globalization has made it easy for terrorists and other separatist movement to rise in Africa .This can clearly be seen from the activities of Jama'atu Ahalis Sunnah Liddah'awati wal jihad (Boko Haram) in Nigeria, the M23 in the Democratic Republic of Congo, the Al-Shabab in Somalia and Kenya. Terrorist activities is seriously affecting development efforts in Africa that is why the post-modernists are calling for a global cognitive mapping on a social and political scale a situation in which individuals and social groups cognitively map their individual and social relationship to local, national and international class realities.

\section{Conclusion/Recommendations}

Postmodernism which is also referred to as late capitalism is thought to be a post industrial society; an informational society and an electronic society. A postmodern society as a social formation has no respect for the laws of capitalism such as the primacy of industrial production. From the above assumption of postmodernism, Africa has joined its band wagon in whatever forms because globalization has affected the Continent politically, socially, economically and culturally.

The level of infrastructural development has improved significantly in Africa as such it was very easy for Africa to leap frog into the post modern era. The effect of this form of development (postmodernism) on Africa cannot be over emphasized. First, Africa's rich cultural heritage is gradually disappearing as western culture is now becoming the dominant culture in the world. Africa is finding it difficult to compete politically and economically at the global stage due to its slow pace of development. Postmodernism has given birth to individualism and social groups as we now have in Nigeria. The rise of the Yusufiwa brotherhood (Boko Haram) in Northern Nigeria and the Movement for the Emancipation of the Niger Delta (MEND) and other geopolitical militias could be said to be by products of postmodernism.

In other to protect Africa's culture, identity and economy from foreign domination or late capitalism as postmodernism is calling, African leaders must initiate policies and programmes that would make the continent self reliant instead of over depending on globalization and its negative influence.

It is true that no country is an island that does not mean that Countries particularly developing economies such as Africa to allow its economy to be dominated by the imperialist west. African leaders should therefore come up with strong protectionist policies of international trade to protect the local industries. The activities of the Chinese and Americans in Angola, Sudan, Ghana, Nigeria etc. should be of great concern to Africans as this crop of neo-colonialists and still plundering the resources of Africa thus putting Africa's development efforts in peril.

Finally it is true that information is power. If African citizens are not informed then they would continue to be raped mentally, politically, socially and culturally. It is therefore not out of place if African leaders can regulate the access to the use of the internet as it is not everything that is accessed in the net that is useful. Africa can take a leaf from the Chinese and the Iranians as regards to the use of the internet. This would go a long way in protecting the culture, customs, religion and other vital aspects of our lives in Africa. 


\section{References}

[1]. L. Banjo "IMF, World Bank,WTO, the wicked machines of the imperialist" Sunday Tribnue Newspaper 23 rd April $2000 . P 19$

[2]. L. Banjo "IMF, World Bank, WTO, the wicked machines of the imperialist" Sunday Tribune Newspaper 23 rd April $2000 . P 19$

[3]. K. Marx, from modern to postmodern social theory (and beyond). Contemporary theories of modernity in Ritzer, G.( ed.) New Delhi McGraw Hill Publication. 2008

[4]. M. Weber, From Modern to postmodern social theory (and beyond): Contemporary theories of Modernity in Ritzer G), Ed. New Delhi Mc 2008

[5]. A. Giddens, Juggernaut of Modernity in Ritzer, G. (Ed.) Modern sociological theory. New Delhi McGraw- Hill 2008

[6]. W.W Rostow, Case of developed and developing countries in Johari J.C New Comparative Government. (Ed.) New Delhi Lotus press 2006

[7]. J.C Johari, New Comparative Government Lotus Press, New Delhi 2006

[8]. Kuhn J.F Lyotard,) postmodern conditions: A Report on knowledge. Minneapolis MN: University of Minnesota Press. 1984

[10]. J. Baudrillard, Extreme postmodern social theory in Ritzer, G (Ed.) Modern sociological theory. New Delhi McGraw-Hill. 2008

[11]. R. Rosty, Philosophy and the Mirrow of nature. Princeton N.T. Princeton University Press. 1989

[12]. B. Daniel, Postindustrial society" Retrieved from www.standfordsnaplopediaparlosiophy.com $24^{\text {th }}$ July 2012.

[13] A. Macewan, "'What is new about the International Economy?" Mimeo, University of Massachusetts 1990

[14]. M.P Todaro, Economic Development. New York: Addison Wesley. 2006

[15]. W.D Nordans, W. D and P.A Samuel, "Economics" New Delhi McGraw Hill.2001

[16]. International Monetary Fund (2004) World Economic Outlook.

[17] Encyclopedia Britannica "Multinational Corporations (MNC) Ultimate Reference Suit Chicago.2011

[18]. Microsoft Encarta, Multinational Corporations.2009

[19]. U. Beck, Risk society: Towards a new modernity, London Sage Publications. 1992

[20] Castells, M. ) Informalism and the Network society: The information age, economy society and culture. Malden, Blackwell Publications.1996

[21]. F. Jameson, Moderate postmodern social theory in Ritzer, G. (2008) New Delhi McGraw Hill Publication.1984

[22]. F.Jameson, Postmodernism or the cultural logic of late capitalism. Retrieved on $24^{\text {th }}$ July 2012 from www.standforengelopulapholophy/com.8445.

[23]. R.Helborner, the nature and logic of capitalism. New York: Norton publication.1985

[24] M..Kahler, Multilateralism with small and large numbers in Reigie (Ed.): materialism matters: theory and practice of an institutional form, New York: Columbia University Press

[25]. F.Jameson, Postmodernism or the cultural logic of late capitalism. Retrieved on $24^{\text {th }} \mathrm{July}^{2012}$ from www.standforengelopulapholophy/com.8445 